\title{
Technè
}

La science au service de l'histoire de l'art et de la

préservation des biens culturels

48 | 2019

Les couleurs de l'Antique

\section{The "lost art" of Archaic Greek painting: revealing new evidence on the Pitsa pinakes through MA-XRF and imaging techniques}

L'" art disparu » de la peinture grecque archaïque. De nouveaux indices révélés sur les pinakes de Pitsa par MA-SFX et imagerie

Hariclia Brecoulaki, Giovanni Verri, Brigitte Bourgeois, Francesco Paolo Romano, Andreas G. Karydas, Claudia Caliri, Elena Martín González and Giorgos Kavvadias

\section{(2) OpenEdition}

\section{Journals}

Electronic version

URL: https://journals.openedition.org/techne/2046

DOI: 10.4000/techne.2046

ISSN: 2534-5168

\section{Publisher}

C2RMF

Printed version

Date of publication: 31 December 2019

Number of pages: $34-54$

ISBN: 978-2-11-152831-4

ISSN: 1254-7867

\section{Electronic reference}

Hariclia Brecoulaki, Giovanni Verri, Brigitte Bourgeois, Francesco Paolo Romano, Andreas G. Karydas, Claudia Caliri, Elena Martín González and Giorgos Kavvadias, "The "lost art" of Archaic Greek painting revealing new evidence on the Pitsa pinakes through MA-XRF and imaging techniques", Technè [Online], 48 | 2019, Online since 01 July 2021, connection on 02 April 2022. URL: http:// journals.openedition.org/techne/2046 ; DOI: https://doi.org/10.4000/techne.2046

\section{cc) (1) $\odot$}

La revue Technè. La science au service de l'histoire de l'art et de la préservation des biens culturels est mise à disposition selon les termes de la Licence Creative Commons Attribution - Pas d'Utilisation Commerciale - Pas de Modification 4.0 International. 
Elena Walter-Karydi

\section{Color and perspective in Late Classical painting}

Couleur et perspective dans la peinture grecque à la fin de la période classique
Abstract. The concept of a central perspective, as invented in the Early Renaissance, is unknown in ancient Greek painting. There is no visualization of space either in archaic images, where the figures stand on a continuous ground line, or in early classical ones, when a specific art of perspective (body perspective) is invented and the figures, in contrapposto postures, may stand on ground lines placed at various heights but are still not coordinated in size. Shortly after the middle of the 4th century, there appear new pictorial means: enhanced body perspective, often combined with a ground surface, viewed-from-below body perspective and color perspective. Even with these revolutionary innovations, no space as such comes into being in Greek painting; perspective appears only as applied to bodies.

Keywords. Central perspective, body perspective, enhanced body perspective, body perspective viewed from below, color perspective.
Résumé. La notion de perspective centrale, inventée à la première Renaissance, est inconnue dans la peinture grecque antique. Il n'existe aucune illusion de profondeur dans les images archaïques, où les personnages se tiennent côte à côte sur une même ligne de sol, ni dans celles du début de l'époque classique, où apparaît un art perspectif bien particulier (la perspective corporelle), avec des personnages déhanchés qui peuvent se répartir sur plusieurs lignes de sol, à des hauteurs différentes, mais sans aucune cohérence des dimensions. Peu après le milieu du IV siècle, les peintres se dotent de nouveaux moyens : perspective corporelle améliorée, souvent associée à une représentation de la surface du sol, perspective corporelle vue par en dessous et perspective chromatique. Malgré ces innovations révolutionnaires, on ne trouve aucune organisation de l'espace à proprement parler dans la peinture grecque, où la perspective reste limitée au corps humain.

Mots-clés. Perspective centrale, perspective corporelle, perspective corporelle améliorée, perspective corporelle vue par en dessous, perspective chromatique.

What we call central perspective in painting was invented by the Early Renaissance masters, and they were proud of this achievement: "Oh, che dolce cosa è questa prospettiva", exclaims Uccello, according to Vasari's later testimony.

A famous example is the Flagellation of Christ by Piero della Francesca (fig. 1). The scene takes place in an open gallery in the middle distance and the three figures standing in the foreground on the right hand side are apparently oblivious to it. Being involved with each other, they stand in the open, and the buildings behind them are characterized by their sizes and colors as being farther away. That is, the sizes of the figures and the architecture as well as the intensity of their coloring ${ }^{1}$ are determined according to the distance between them: the painter creates a space, as it were, before setting them in it.

In ancient Greek painting, there is no central perspective. In a characteristic Archaic example, one of the wooden tablets found in the Pitsa Cave, one signed by a Corinthian painter (fig. 2) ${ }^{2}$, the colors are applied evenly, clearly marked

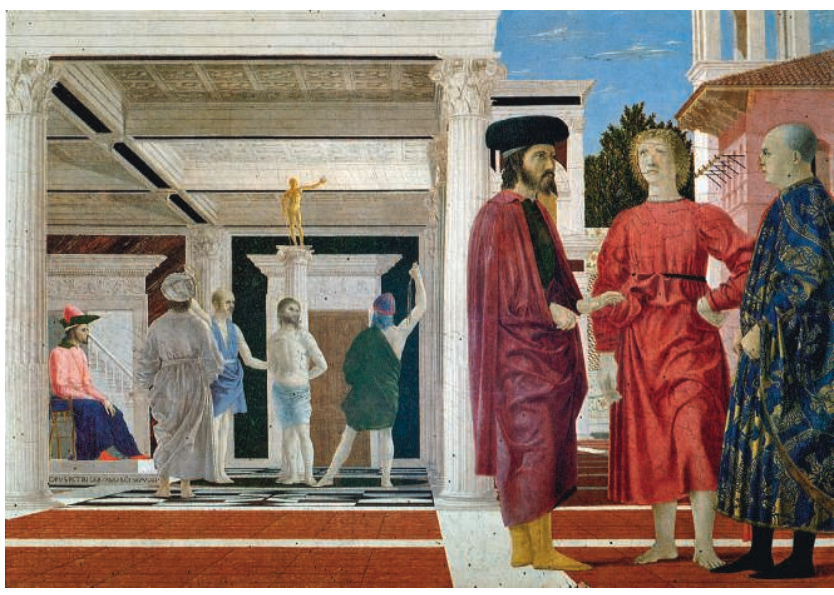

Fig. 1. Piero della Francesca, Flagellation of Christ, c. 1455-1460, oil and tempera on wood panel, Urbino, Galleria Nazionale delle Marche. Open Licence. 


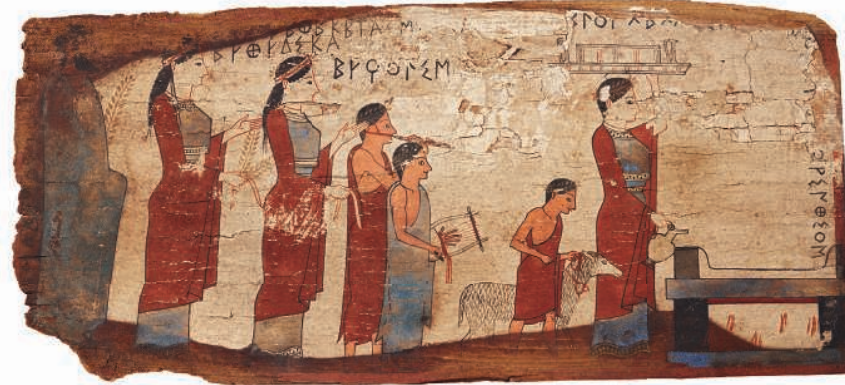

Fig. 2. Sacrificial procession to an altar, wood panel from Pitsa, Corinthia (L. $32.3 \mathrm{~cm}$, w. $15 \mathrm{~cm}$ ), c. 550-540 B.C., Athens, National Archaeological Museum, 16464. (C) With the authorization of the National Archaeological Museum, Athens/C. Simatos.

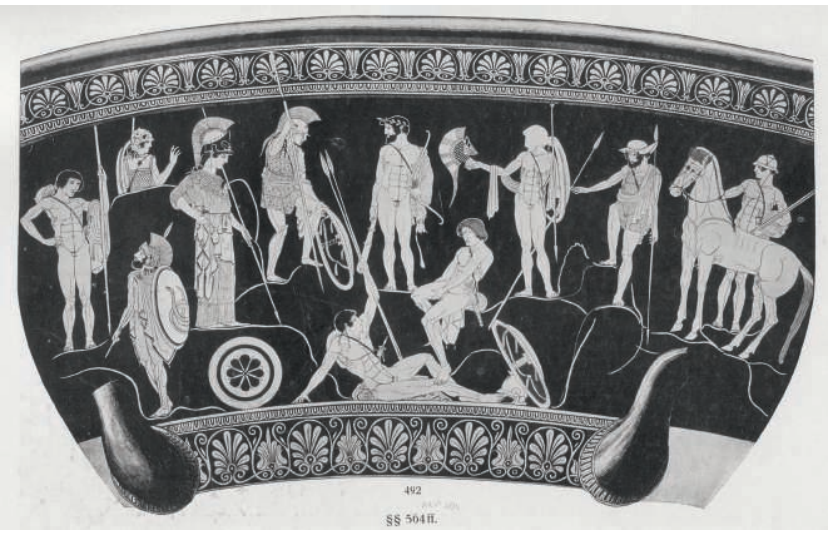

Fig. 3. The Athenians and the polis-goddess in the Herakles-sanctuary before the battle of Marathon, calyx-krater attributed to the Niobid painter, c. 460 B.C., Paris, musée du Louvre, G341, side A (A. Furtwängler, K. Reichhold, Griechische Vasenmalerei II, 1909, pl. 108).

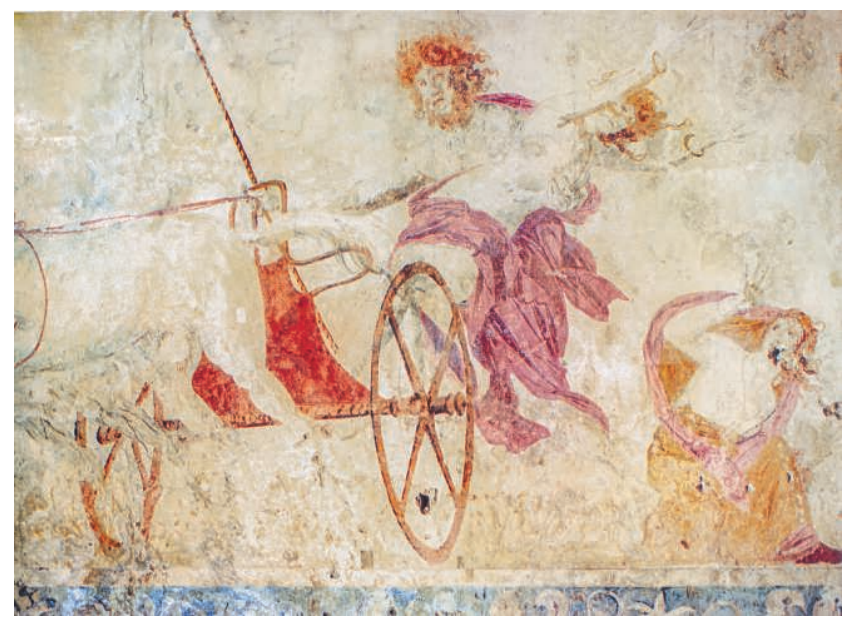

Fig. 4. Pluto abducts Persephone, part of a frieze on three walls of the chamber of Persephone-Tomb (H. $1.01 \mathrm{~m}, 1.3 .50 \mathrm{~m}), c .330$ B.C., Vergina (Andronikos, 1984, pl. 49). archaic paintings, the figures may also be in a frontal, but never in a three-quarters view); moreover, it is obvious that they all stand on a continuous ground line, even if this line is not preserved. There are no background figures; everything is equally present and only an overlapping is possible, as is the case with the sheep led on a rope by a boy or with the flute player accompanying a lyre-player.

Early Classical painters invented what has been aptly called a body perspective ${ }^{3}$, since it occurs only on bodies (of human beings as well as animals and objects), as for instance in the famous scene by the Niobid Painter on a calyx-crater (fig. 3$)^{4}$. The figures appear in contrapposto postures and often in a three-quarter view; they do not stand on a continuous ground line but are disposed at various heights in the scene, on ground lines $^{5}$ (in fine relief, painted white) suggesting a rocky landscape. Yet these figures are still not coordinated proportionately in size according to their distance from each other: the body perspective as such does not create a space in the picture.

This perspective was long lived: it was characteristic for Greek art as a whole ${ }^{6}$. Besides, shortly after the middle of the 4th century, an enhanced body perspective was introduced. In the wall painting of Persephone's abduction (fig. 4$)^{7}$, this perspective is evident in the sharp turn of the chariot, Persephone's pivoting as she is trying to escape Pluto, as well as in the posture of the terrified young girl crouching nearby. It is significant that this perspective too applies only to figures and objects so that there is still no coherent representation of space in the picture. Moreover, while Persephone's abduction certainly takes place in the open air, the background of the scene is an evenly applied white that has neither a representational nor a spatial value; there is no blue sky as in the Quattrocento painting previously discussed (fig. 1).

The enhanced body perspective was apparently much appreciated, as is suggested by Pliny's praise of the Sicyonian painter Pausias (middle of the 4th century B.C.) who, in a large picture of an ox sacrifice, is said to have invented a method of painting, copied by many but equaled by none, the chief point being that the animal stood, not as usual, sideways but faced the spectator, but in such a way as to convey its great size ${ }^{8}$. Whether it was actually Pausias who invented the enhanced body perspective remains, however, an open question.

An innovation, as revolutionary in its way as the ground lines (fig. 3), was the rendition of the ground surface, introduced shortly after the middle of the 4 th century. It suited the effect of the enhanced body perspective, as can be seen in the masterpieces of the royal hunt wall painting, decorating the facade of Philip's II tomb in Vergina, and the Alexander mosaic from the Casa del Fauno in Pompei (fig. $5^{9}$ and $6^{10}$ ).

The hunt (fig. 5) takes place in a hilly ground with trees and rocks, a grove whose sacred character is shown by a high pillar with three statuettes as well as the ribbons tied around a tree. In such groves, the Macedonians kept wild animals for the royal hunt ${ }^{11}$ and conducted sacrifices to the gods. The hunters, accompanied by their dogs, take aim at stags, a boar and a bear, but the main group is that around a lion. Men and animals, shown moving in enhanced body perspective and 

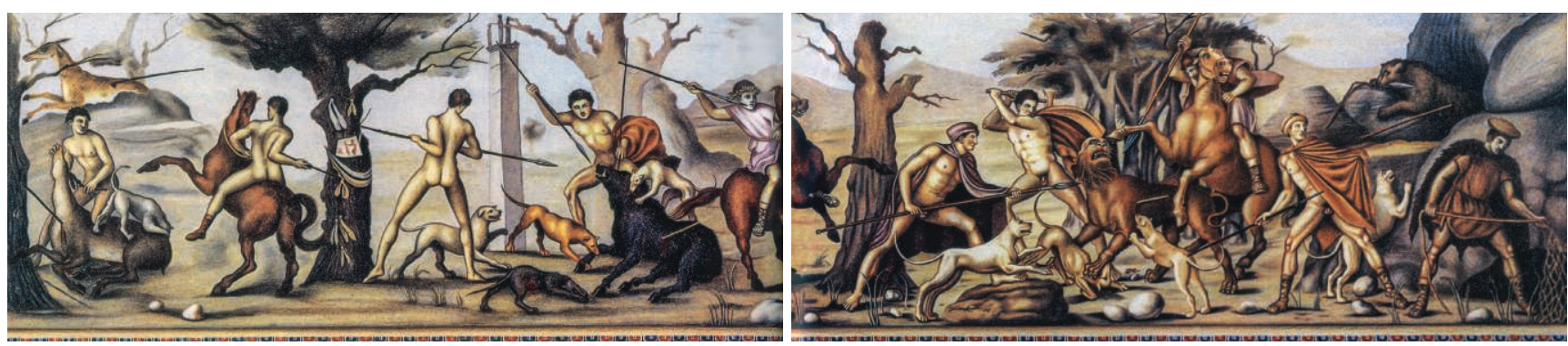

Fig. 5. Hunt Frieze, on the façade of Philip II's tomb (copy by G. Miltsakakis) (H. 1.12 m, 1. 5.56 m), c. 330 B.C.,

Vergina (Brecoulaki, 2006, pl. 27b).

on a ground surface, do indeed suggest space - yet this does not actually come into being, since the figures' sizes are not adjusted to their positions in the scene. For instance, the wounded deer fleeing behind a rock on the left is no smaller than the figures in the right foreground. This independence in size is only one of the features distinguishing the hunt frieze from the Flagellation of Christ (fig. 1).

The choice of subject for the frieze was significant: a lion hunt was considered a contest in which the king proved his valor as in a battle; no one else was allowed to kill the beast. The bearded rider, who aims the decisive blow at the lion and is distinguished by an extremely enhanced body perspective must be the dead king Philip II, while the wreathed youth riding recklessly towards them, distinguished through his central position in the frieze, must be Alexander; father and son are the only riders in this group. The painting suggests that Alexander, as a daring rider and Philip's closest companion, is exceptionally suited to be his father's successor.

The most famous mosaic in Antiquity (fig. 6) is a copy of a painting representing Alexander the Great confronting King Darius III on the battlefield ${ }^{12}$. The exquisite quality of the opus vermiculatum allows rich color shades that must have followed closely the coloring of the original. In fig. 6 , some parts of the Alexander mosaic are omitted: the dentil border (it is generally accepted that this, frequently found in Hellenistic mosaics, has nothing to do with the original painting), as well as the brown strip under the main field ${ }^{13}$ and the upper part of the sky ${ }^{14}$; apparently, both were added in order to make the mosaic fit in the available space in the exedra of the Casa del Fauno. The hunt frieze (fig. 5) might give an idea of the height of the sky in the original painting of the Alexander mosaic. In Greek images, the sky is never shown to such an extent and height as it is, for instance, in Dutch paintings of the 17 th century, where it plays a decisive role in the composition. The Greek masters, when it is necessary for the story to represent the sky, do it in a concrete fashion: e.g. in the part of the Persephone frieze, left of the abduction group (fig. 4), there appears Hermes, running in front of the chariot, leading the way; above him, in the upper corner, there is on the white ground a small blue patch, representing the sky, whence radiate the wavy lines of Zeus' thunderbolt ${ }^{15}$, suggesting that the greatest god is also present and so emphasizing the cosmic significance of this abduction.

The pictorial means mentioned above were a matter of choice on the part of each painter; for instance, in the abduction scene (fig. 4), there is a ground line instead of a ground surface; only some tiny flowers suggest the meadow where Persephone was abducted. In contrast, the painter of the densepacked fighting scene (fig. 6) did not forego a ground surface. A Persian tries to stop Alexander - who rides headlong against the center of the enemy army towards Darius - but can only grab at Alexander's spear as it pierces him through; dying, he raises his left arm in a dramatic gesture expressing his agony. He and his collapsing horse are shown almost frontally, in an enhanced body perspective that reminds us of Pausias' bull (see above), and the same applies to the next horse, seen from behind, which a Persian is trying to turn around.

Nothing stops Alexander as he, fighting as primus inter pares, makes headway towards Darius. The latter, however, standing high above his own men on his chariot has given up the fight; he stretches his right hand out in a helpless gesture, holding his bow in the left. His driver has already changed the chariot's direction; holding the whip high, he urges the horses forward (their enhanced body perspective stresses the need for flight), even running down Darius' own warriors: one lies already under the horses that trample over him, another falls

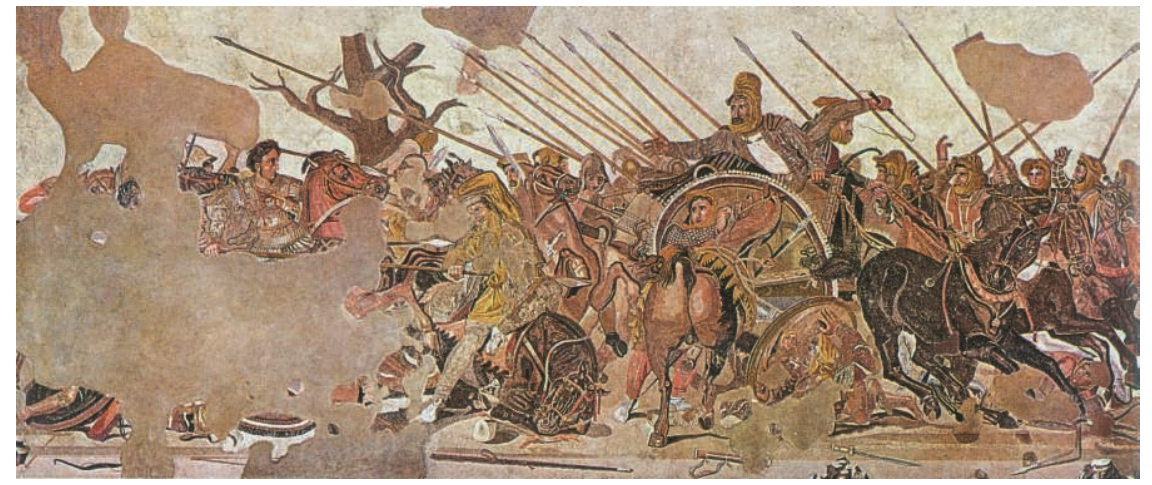

Fig. 6. Alexander mosaic, from the Casa del Fauno, Pompeii (1. 5.12 m), c. 100 B.C., copy of a painting of $c$. 330-325 B.C., Naples, National Museum. 


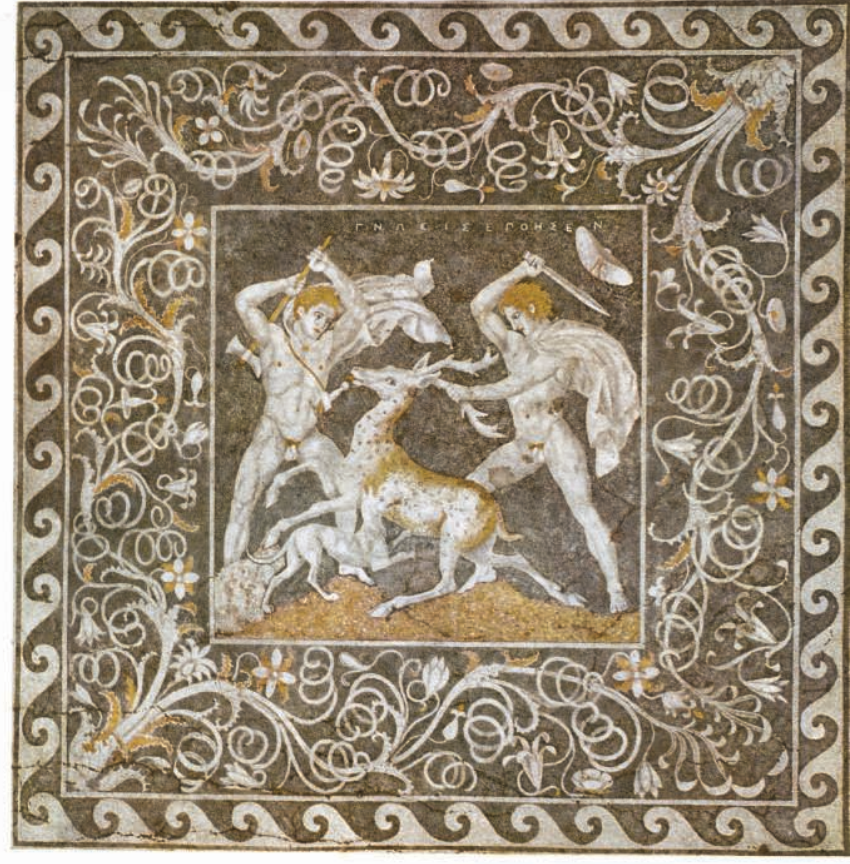

Fig. 7. Stag hunt mosaic, signed by Gnosis (3.10 m x $3.10 \mathrm{~m})$, Pella, House of the abduction of Helena, c. 320 B.C., Pella, Archaeological Museum.

under the wheels, dying in a posture of enhanced body perspective, his face mirrored in a standing shield.

In the years of the hunt frieze and of the original painting copied in the Alexander's battle scene, the mosaic masters carried out their works in a manner more closely to painting than previously, adopting several of the innovations that had been only just introduced in it, like the enhanced body perspective (as well as shading, which will not be discussed here). This development is evident in the outstanding piece by Gnosis (fig. 7$)^{16}$. On a hilly ground surface, two hunters and their dog attack a stag by surrounding it; there is a striking similarity to the hunter groups in fig. 5: they all show enhanced body perspective. Moreover, this perspective distinguishes also the tendrils on the border of the figural scene, a vegetable ornament of exquisite quality: apparently Gnosis did not leave its execution to some assistant in his workshop but carried it out himself.

Another innovation, also introduced shortly after the middle of the 4th century, is the perspective view from below, as seen in a painted grave portrait (fig. 8) ${ }^{17}$. The posture of Hermon sitting on a throne shows an enhanced body perspective, but the view from below heightens even more the impact of the portrait. (Its high quality was not unusual since funerary paintings were frequently done by renowned masters, such as Nikias ${ }^{18}$.) This viewed-from-below perspective, introduced in these years also into painted dentils and meander ornaments, occurred frequently in Hellenistic wall decorations and mosaic borders enhancing their plastic effect.

Another invention in the years shortly after the middle of the 4th century is the color perspective: in paintings with a ground surface, things represented as farther away are muted in color. In the hunt frieze (fig. 5), the trees in the foreground are dark brown while those behind the lion group show by their pale coloring that they stand farther away; still farther away must be the bare tree behind the boar group as well as the small bare tree behind the wounded deer on the left. The rocks are likewise differentiated in color, thus revealing their position in the landscape, and the back of the ground surface is shaped as hills that are pale-colored and thus seem to lie far away. Accordingly, the color perspective that makes the single tree in the Alexander mosaic (fig. 6) take on a faded color and so locates it in the background of the battle, was a feature of the original painting ${ }^{19}$.

There is an essential difference between the color perspective in the late classical period and that in the Quattrocento paintings, which was defined by Leonardo as identical with the air perspective. There is no sense of air in the Greek paintings since in them there is no space; the color perspective concerns only the figures and objects. These may be shown to be located in the background through their pale coloring, but appear not a whit smaller in size than those in the foreground, unlike the Quattrocento painting. Even in the masterpieces (fig. 5 and 6), where all the pictorial means I have mentioned were applied, there still results no space as a continuous whole where the position of every single item determines its size and its color intensity.

All in all, in ancient Greek painting, the pictorial means apply exclusively to the figures and objects: the predominant focus on the body remains unchallenged. Erwin Panofsky claimed that Greek painters created an aggregate of space (Aggregatraum), not a systematized space (Systemraum) as do the painters of modern age ${ }^{20}$. But actually, it seems rather that the entire notion of space must be reconsidered: in the ancient Greek paintings, there appear only bodies.

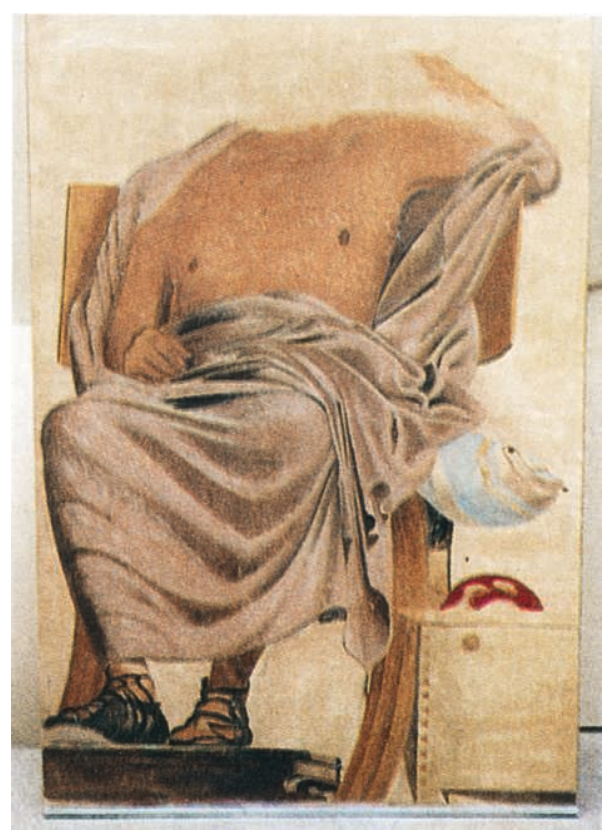

Fig. 8. Hermon, son of Athenokles (copy), back slab of a grave naiskos (H. $1.06 \mathrm{~m}$ ), c. 340 B.C., Athens, Kerameikos Museum, 1515. (C) U. Knigge. 
Notes

1. Color perspective is discussed further below.

2. Walter-Karydi, 1986, p. 25ff. fig. 1; Brecoulaki et al., 2017, and Brecoulaki et al. in this volume.

3. Schweitzer, 1953, p. 13

Körperperspektive.

4. $A R V^{2}$ p. $601,22.1661$; Para p. 395; $A d d^{2}$ p. 266; $B A$ 206954. - Ever since this vase was found the scene (fig. 3) has been interpreted in several different ways, but at last Martine Denoyelle found out that the figure of Herakles stands on a base and is therefore a statue (1997, p. 35-38 fig. 29 [drawing, by the conservator Christine Merlin]). Denoyelle argued that the theme, inspired by Mikons' wall painting, was "une expédition guerrière placée sous la protection d'un Herakles divinisé, assisté par Athena... des guerriers figurant idéalement les Marathonomaques" before or after the battle of 490 B.C. (ibid., p. 39-41). Luca Giuliani (2015, p. 57-63. 74-83 fig. 12) corrected part of the drawing by Denoyelle and claimed convincingly that the scene represents the Athenians and the polisgoddess at the Herakles-sanctuary of Marathon before the battle of 490 B.C.

5. More or less weathered, some of them are now hardly visible to the naked eye. On such ground lines, see the apt comments by Dietrich, 2010, p. 230-240.

6. I cannot follow Schweitzer (1953, 13ff.) in that a spatial perspective (Raumperspektive) replaced the body perspective in the 4 th century B.C.

7. Wall paintings of the so-called Persephone Tomb: Andronikos, 1994 Brekoulaki, 2006, p. 77-100, pl. 11-25; Kottaridi, 2007.

8. HN 35, 126-127; DNO 2703

9. Andronikos (1984, p. 97ff.) identified the tomb as that of Philipp II, who was murdered 336 B.C. See Saatsoglou-Paliadeli, 2004; Brecoulaki, 2006, p. 101-133 pls. $26-46$. Some scholars date the tomb 20 years later and attribute it to Philipp III Arrhidaios (see above all Borza, Palagia, 2007). Besides the copy fig. 6 , see now the excellent photos of the original: SaatsoglouPaliadeli, Brinkmann, 2013.

10. Hölscher, 1973, p. 122-169; Andreae, 1977; Stewart, 1993, p. 130-150; Cohen, 1997; Mielsch, 2008. Casa del Fauno and mosaics: Hoffmann, De Vos, 1994; Faber, Hoffmann, 2009.

11. Polybios XXXI.

12. Here I cannot enter into the various interpretations of the original painting or its attribution to an artist.

13. Most scholars see this strip as part the original painting, yet Pernice, 1908, 11 already pointed out that it is an addition.
14. Most scholars believe that the extensive sky was in the original painting too. 15. Andronikos, 1994, pl. V; Brecoulaki, 2006, pl. 12,1 ; Kottaridi, 2007, p. 28 , fig. 3 and p. 31 , fig. 6 . For representations of the sky in Greek art, see Walter-Karydi, 2003, p. 183-185, fig. 334 (laconian cup), 335-336 (metope of the Zeus temple in Olympia).

16. Salzmann, 1982, no. 103 pl. 29. 101, 2-6; 102, 1-2: c. 340-30/320-10 B.C.; Rouveret, 1989, p. 237, c. 316, see ibid. 286290; Andreae, 1983, fig. 23: c. 310 B.C.

17. Walter-Karydi, 2015, colour pl. III.

18. DNO 2810. 2817.

19. Hölscher, 1973, 158ff. n. 979 rightly rejected the notion that the color perspective of the tree was an addition by the copyist.

20. Panofsky, 1927, p. 109.

\section{Bibliography}

Andreae B., 1983, Antike Bildmosaiken, Mainz. Andronikos M., 1984, Vergina. The Royal Tombs and the Ancient City, Athens.

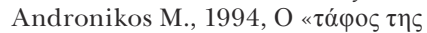

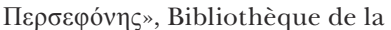
Société archéologique, Athènes.

Borza E. N., Palagia O., 2007, "The Chronology of the Macedonian Royal Tombs at Vergina”, Jahrbuch des Deutschen Archäologischen Instituts 122 , p. $81-125$.

Brecoulaki H., 2006, La peinture funéraire de Macédoine. Emplois et fonctions de la couleur, $I V^{e}-I I^{e}$ siècles av. J.-C., National Hellenic Research Foundation, Mélétèmata 48, KERA, Athens.

Brecoulaki H., Kavvadias G., Kantarelou V., Stephens J., Stephens A., 2017, "Colour and Painting Technique on the Archaic Panels from Pitsa, Corinthia”, in St. T. A. M. Mols, E. M. Moormann (eds.), Context and Meaning, Proceedings of the 12 th international Conference of the Association internationale pour la peinture murale antique, Athens, 2013, LeuvenParis-Bristol, CT, p. 15-23.

Cohen A., 1997, The Alexander Mosaic: Stories of Victory and Defeat, Cambridge.

Denoyelle M., 1997, Le cratère des Niobides, RMN/Musée du Louvre Éditions, Paris.

Descamps-Lequime S. (dir.), 2007, Peinture et couleur dans le monde grec antique, Actes du colloque, 5 Continents Éditions/ Musée du Louvre Éditions, 2004.

Dietrich N., 2010, Figur ohne Raum, Berlin/ Boston.

Faber A., Hoffmann A., 2009, Die Casa del Fauno in Pompeji (VI 12) I, Wiesbaden.

Giuliani L., 2015, Das Wunder vor der Schlacht: ein griechisches Historienbild der frühen Klassik, Basel.
Hölscher T., 1973, Griechische Historienbilder des 5. und 4. Jahrhunderts, Würzburg.

Hoffmann A., De Vos M., 1994, "Casa del Fauno (VI, 12, 2)”, in G. Pugliese Carratelli, I. Baldassare et al. (eds.), Pompei. Pitture e mosaici V, Istituto della enciclopedia italiana, Roma, p. 80-141.

Kansteiner S., Hallof K., Lehmann L., Seidensticker B., Stemmer K., Mielsch H. et al. (eds.), 2014, Der Neue Overbeck, Berlin/Boston.

Kottaridi A., 2007, "L'épiphanie des dieux des enfers dans la nécropole royale d'Aigai", in S. Descamps-Lequime (dir.), p. 27-45.

Mielsch H., 2008, "Kopien in Mosaiken und Wandmalereien”, in K. Junker, K. Stähli (eds.), Original und Kopie, colloquium Berlin, 2005, Wiesbaden, p. 178-181.

Panofsky E., 1927, "Die Perspektive als symbolische Form", in H. Oberer, E. Verheyen (eds.), Aufsätze zu Grundfragen der Kunstwissenschaft (1974, second edition), Berlin.

Pernice E., 1908, "Nachträgliche Bemerkungen zum Alexandermosaik", Mitteilungen des Deutschen Archäologischen Instituts, Römische Abteilung 23, p. 11-14.

Rouveret A., 1989, Histoire et imaginaire de la peinture ancienne ( $V^{e}$ siècle av. J.-C.- $I^{e r}$ siècle ap. J.-C.), École française de Rome, Rome.

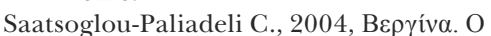

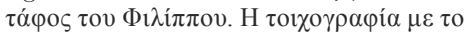
$\kappa v \vee \eta ́ \gamma ı$, Athens.

Saatsoglou-Paliadeli C., Brinkmann V., 2013, "Der Jagdfries am Grab Philipps II im Vergina-Aigai”, in R. Gebhard, E. Rehm, H. Schulze (eds.), Alexander der Große, Herrscher der Welt, exhibition Rosenheim, p. 194-201.

Salzmann D., 1982, Untersuchungen zu den antiken Kieselmosaiken, Berlin.

Schweitzer B., 1953, Vom Sinn der Perspektive, Tübingen.

Stewart A., 1993, Faces of Power: Alexanders Image and Hellenistic Policies, BerkeleyLos Angeles-Oxford.

Walter-Karydi E., 1986, "Prinzipien der archaischen Farbgebung”, in K. Braun, A. Furtwängler (eds.), Studien zur klassischen Archäologie, Festschrift F. Hiller, Saarbrücken, p. 23-41.

Walter-Karydi E., 2003, "Das Kolorit des Reliefgrundes in der archaischen und der klassischen plastic der Griechen", in V. Brinkmann, R. Wünsche (eds.), Bunte Götter. Die Farbigkeit antiker Skulptur, exhibition Glyptothek München, p. 180-185.

Walter-Karydi E., 2015, Die Athener und ihre Gräber, Berlin/Boston. 